\title{
Toxicity and Genotoxicity in HeLa and E. coli Cells Caused by a Helium Plasma Needle
}

\author{
E. García-Alcantara ${ }^{1,2}$, R. López-Callejas ${ }^{1}$, J. Serment-Guerrero ${ }^{1}$, R. Peña-Eguiluz ${ }^{1}$, A. E. Muñoz-Castro ${ }^{1}$, \\ B. G. Rodríguez-Méndez ${ }^{1}$, A. Mercado-Cabrera ${ }^{1}$, R. Valencia-Alvarado ${ }^{1}$, A. de la Piedad-Beneitez ${ }^{2}$, \\ J. M. E. Contreras-Ortíz $z^{3} \&$ A. Barbabosa-Pliego ${ }^{3}$
}

\author{
${ }^{1}$ Plasma Physics Laboratory and Radiobiology Laboratory, Instituto Nacional de Investigaciones Nucleares, A.P. \\ 18-1027, Mexico D. F., Mexico \\ ${ }^{2}$ Instituto Tecnológico de Toluca, A.P. 890, Toluca, Mexico \\ ${ }^{3}$ Centro de Investigación y Estudios Avanzados en Salud Animal, Facultad de Medicina Veterinaria y Zootecnia \\ Universidad Autónoma del Estado de México, Autopista Toluca-Atlacomulco km 15.5, Toluca, Estado de \\ México, México
}

Correspondence: J. Serment-Guerrero, Plasma Physics Laboratory and Radiobiology Laboratory, Instituto Nacional de Investigaciones Nucleares, A.P. 18-1027, 11801, Mexico D. F., Mexico. E-mail: jorge.serment@inin.gob.mx

Received: June 9, 2013 Accepted: July 9, 2013 Online Published: July 31, 2013

doi:10.5539/apr.v5n5p21

URL: http://dx.doi.org/10.5539/apr.v5n5p21

\begin{abstract}
The aim of this study is to determine the toxic and genotoxic damages produced by a helium plasma needle upon HeLa and E. coli (OG100 and PQ30) cell cultures. For HeLa cells survival (MTT) and microelectrophoresis comet) assays were performed; meanwhile in $E$. coli, viable count and genotoxicity by the chromotest were evaluated. The outcomes indicate that the plasma exposures on HeLa cells undergo more toxicity and genotoxicity as treatment time increases. With respect to E. coli, plasma exposure generated toxicity, but no genotoxicity could be detected with this system. In the strain OG100, defective in a protection mechanism to oxidizing agents, there was a reduction in the survival of one order of magnitude compared to the wild type strain PQ30. It suggests that such reduction is due to the plasma by means of the reactive oxygen and nitrogen species (RONS) generated during atmospheric air interaction.
\end{abstract}

Keywords: cold plasma, Plasma treatment, oxygen and nitrogen species (RONS), cytotoxicity, genotoxicity

\section{Introduction}

In physics, plasma is defined as an ionized gas containing free charge carriers (ions and electrons), active radicals and excited molecules (Kogelschatz, 2003). Plasmas at atmospheric pressure and low temperature are subdivided in thermal (quasi-equilibrium) and non-thermal (out of equilibrium). In the first case, the temperature is in the order of $10^{4} \mathrm{~K}$ and the electron density is equal to or bigger than $10^{20} \mathrm{~m}^{-3}$ for non-thermal plasmas, temperature is in the 300 to $1000 \mathrm{~K}$ range and electron density is approaching $10^{10} \mathrm{~m}^{-3}$ (Chen, 1984; Chen, 2008; Fridman, 2008).

In the last years, non-thermal plasmas have been used for many purposes, i.e. surface sterilization and heat sensitive medical material (Laroussi, 1996; Lerouge et al., 2001; Nehra et al., 2008; Fridman, 2008), living tissue treatment such as wound healing and sterilization (Kieft et al., 2005; Laroussi, 2009), blood coagulation (Fridman, 2008), skin treatments (Fridman et al., 2007; Fridman, 2008), bacteria inactivation such as gram positive, negative, aerobic, anaerobic (Moisan et al., 2001; Laroussi et al., 2002; Sladek et al., 2004; Goore et al., 2006; Gallagher et al., 2007; Martines et al., 2009; García et al., 2011), spores (Moisan et al., 2006; Laroussi et al., 2002; Fridman et al., 2010), disinfection of dental cavities or bacterial contaminated food (Sladek et al., 2004; Fridman et al., 2010), and functional or structural modification of cancer cells (Stoffels, 2003; Fridman, 2008; Zimheld et al., 2010; Robert et al., 2012).

The non-thermal plasma devices most used in medical applications are dielectric barrier discharge (DBD), floated electrode-dielectric barrier discharge (FE-DBD), plasma jets and plasma needle (Fridman, 2008). From a physical point of view, it is possible to distinguish two plasma exposure modes: direct and indirect (Fridman, 
2008). In the former, the active plasma is in direct contact on the surface (Stoffels, 2003; Stoffels et al., 2006), hence the energy transfer to the surface is optimal and the flow directed of ROS is the highest (Fridman, 2008). This kind of treatment is commonly recognized as the most effective in terms of surface modification and sterilization. In the latter, also known as post-discharge treatment, the plasma effluents are directed on to the surface, and some short-live reactive species are unable to reach the objects to be treated. The efficiency is much smaller than in the direct treatment (Moisan et al., 2001; Moisan et al., 2006; Fridman et al., 2007). However, when it comes to living tissue treatments or liquid decontamination, there are still many issues to be solved. One of such problems is the action mechanisms involved in the cytotoxicity of the non-thermal plasmas. In this research, a plasma needle was applied upon HeLa cells and E. coli bacteria, and its influence on growth bacterial and cell cultures was analysed.

\section{Materials and Methods}

\subsection{Plasma Needle}

The plasma needle reactor has a coaxial configuration which generates a non-thermal plasma, the nozzle has 1 $\mathrm{mm}$ of radius, in the centre has a copper filament surrounded by an insulating ceramic support, which provides both rigidity and mechanical protection, (Figure 1) (Pérez et al., 2008). The plasma is produced by a radiofrequency generator at $13.56 \mathrm{MHz}$ in a helium environment at a 1 SLPM flow.

The plasma diagnostic was assessed by spectroscopy using a $\lambda$-Minuteman monochromator 305 -SMP (Minuteman, 1979), end owed with a $0.5 \mathrm{~m}$ focal length Czerny-Turner coma-corrected optical system and interchangeable gratings. According to the wavelength range $(200-800 \mathrm{~nm})$, a R955 photomultiplier tube (PM) with a compatible spectral sensitivity was installed. Finally, a $3 \mathrm{~m}$ long quartz optical fiber of $1 \mathrm{~mm}$ diameter core, matched with the monochromator, has been located at $\sim 5 \mathrm{~mm}$ from the plasma.

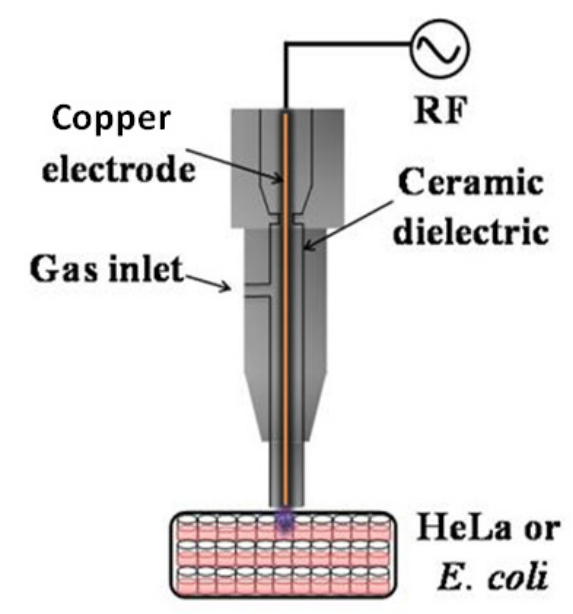

Figure 1. Diagram of the plasma needle reactor

\subsection{HeLa and E. coli Cells Preparation}

HeLa cells were grown at $310.15 \mathrm{~K}$ in an atmosphere of $5 \% \mathrm{CO}_{2}$ in minimal essential medium (MEM) supplemented with $10 \%$ bovine fetal serum until subconfluent phase was reached. Cells were harvested using trypsin-versene and resuspended in MEM, counted, and then $1.2 \times 10^{4}$ cells per well were placed in a plate of 96-well with $100 \mu \mathrm{L}$ of MEM for 24 hours at $310.15 \mathrm{~K}$.

PQ30 and OG100 E. coli strains were used, which possess the genetic markers needed to assess genotoxicity by means of the SOS Chromotest (Quillardet et al., 1985). Briefly, $0.3 \mathrm{~mL}$ of overnight cultures of each strain were diluted in $15 \mathrm{~mL}$ of Luria Bertani broth and incubated with constant agitation at $310.15 \mathrm{~K}$ until a concentration of $2 \times 10^{8}$ cells $/ \mathrm{mL}$ was reached. Cultures were centrifuged at $10,000 \mathrm{rpm}$ for 10 minutes, supernatant was discarded, pellets were resuspended in the same volume of $0.02 \mathrm{M}$ phosphate buffer and $1 \mathrm{~mL}$ aliquots were distributed into a 32-wells titration plate.

\subsection{Plasma Exposure}

The two different cellular types were treated with Helium plasma in a liquid media to ensure a homogeneous 
exposition. The helium plasma needle was used on culture of HeLa cells and E. coli bacteria at a distance of 2 $\mathrm{mm}$ from the reactor outlet. In particular, for HeLa cells treatments were of 30, 60, 120, and 180 seconds for the viability study and 10,15, 20 and 30 seconds for the comet assay. In the case of $E$. coli bacteria, plasma exposure times were 60,180, 300 and 400 seconds for the viable count and finally, evaluation of SOS response activation was carry out at $30,60,120$ and 180 seconds.

\subsection{MTT Survival Assay}

The MTT assay (3-[4,5-dimethylthiazol-2-yl]-2,5-diphenyl tetrazolium bromide) is a biosynthetic enzyme test which has proven to be highly reliable to assess survival and proliferation capacity of mammalian cells. In this test, the mitochondrial dehydrogenase oxidizes the yellow molecule MTT, thus generating a blue coloration (formazan) whose intensity will vary according to cell viability (Tice et al., 2000).

After applying the plasma needle treatment upon HeLa cells, the MEM was removed and $100 \mu \mathrm{L}$ of serum was deposited in each well; $50 \mu \mathrm{L}$ of MTT $(5 \mu \mathrm{g} / \mathrm{mL})$ were added, and incubated for further 4 hours at $310.15 \mathrm{~K}$ in $5 \%$ of $\mathrm{CO}_{2}$ atmosphere. Afterwards $100 \mu \mathrm{L}$ of isopropanol were added to dissolve the formazan crystals and further incubated for 30 minutes at $310.15 \mathrm{~K}$ in $5 \%$ of $\mathrm{CO}_{2}$ atmosphere. Finally, colour intensity was measured with a spectrophotometer using a wavelength of $540 \mathrm{~nm}$.

\subsection{Comet Assay}

The comet assay, also known as microlectrophoresis, is a technique that allows assessment of DNA damage and repair in any eukaryotic cell individually, resulting in the formation of a similar image to the comet tail. This assay was performed according to the protocol described by Cotelle et al. (1999).

After plasma treatment, HeLa cells were mixed with an equal volume of $1 \%$ low melting point agarose in HBSS (Hank's Balanced Salt Solution), so the final concentration is $0.5 \% .90 \mu \mathrm{L}$ of this suspension were poured on a fully frosted slide previously layered with $90 \mu \mathrm{L}$ of $0.5 \%$ regular agarose and let stand for 5 minutes.

Subsequently, the slides were immersed in a lysis solution $\left(2.5 \mathrm{M} \mathrm{NaCl}, 100 \mathrm{mM} \mathrm{Na}_{2}\right.$ EDTA, 100mM Tris, $1 \%$ Na sarcosinate, $1 \%$ TRITON X100, 10\% DMSO, pH 10) for one hour and then transferred to an electrophoresis chamber, covered with the electrophoresis solution ( $0.3 \mathrm{M} \mathrm{NaOH}, 1 \mathrm{mM}$ EDTA) for 30 minutes to allow DNA unwinding. Electrophoresis was carried out at $20 \mathrm{~V} / 300 \mathrm{~mA}$ for 20 minutes. The slides were rinsed 3 times with neutralizing buffer ( $0.4 \mathrm{M}$ Tris- $\mathrm{HCl}, \mathrm{pH} 7.4)$ and each slide was stained with $60 \mu \mathrm{L}$ of ethidium bromide (20 $\mu \mathrm{g} / \mathrm{mL}$ ). The analysis was performed in a Hund Wetzlar fluorescence microscope using the 515-560 nm excitation filters green light (Comet Assay IV, Perceptive Instruments Inc.).

\subsection{Viable Count}

After plasma treatments, bacterial suspensions were properly diluted with phosphate buffer $(0.02 \mathrm{M}, \mathrm{pH} 7)$, plated and incubated for 24 hours at $310.15 \mathrm{~K}$. Colonies were counted and survival percent was calculated for each time taking the untreated control as $100 \%$.

\subsection{SOS Response}

The SOS response is a system formed by about 60 genes involved in tolerance to genetic damage or DNA repair mechanisms. Under normal circumstances these genes are repressed, but when DNA damage occurs the expression levels of these genes raise to try to cope with such lesions. SOS activity was evaluated by means of the chromotest. Briefly, aliquots of the treated cell suspensions were diluted 10-fold in LB, incubated at 310.15 $\mathrm{K}$ for the appropriate time to allow the expression of the SOS response and mixed afterwards with the proper buffer and $\beta$-galactosidase substrate (ONPG). Another series of tubes was prepared similarly for the alkaline phosphatase assays with p-nitrophenyl phosphate (PNPP) as substrate. Both series were then incubated until a yellow colour appeared (or up to 90 minutes). The reactions were then stopped as indicated by Quillardet and Hofnung and absorbency was read spectrophotometrically at $420 \mathrm{~nm}$.

\section{Results and Discussion}

Figure 2 shows the emission bands and peaks of helium discharge in the wavelength range of 200-800 nm which are mainly: hydroxyl radicals $(\mathrm{OH})$ in the band of $306 \mathrm{~nm}\left(\mathrm{~A}^{2} \Sigma^{+} \rightarrow \mathrm{X}^{2} \Pi, 0-0\right)$, the second positive system of $\mathrm{N}_{2}$ in the bands $295 \mathrm{~nm}\left(\mathrm{C}^{3} \Pi_{\mathrm{u}} \rightarrow \mathrm{B}^{3} \Pi_{\mathrm{g}}, 4-2\right), 316 \mathrm{~nm}\left(\mathrm{C}^{3} \Pi_{\mathrm{u}} \rightarrow \mathrm{B}^{3} \Pi_{\mathrm{g}}, 1-0\right), 337 \mathrm{~nm}\left(\mathrm{C}^{3} \Pi_{\mathrm{u}} \rightarrow \mathrm{B}^{3} \Pi_{\mathrm{g}}, 0-0\right), 375 \mathrm{~nm}$ $\left(\mathrm{C}^{3} \Pi_{\mathrm{u}} \rightarrow \mathrm{B}^{3} \Pi_{\mathrm{g}}, 1-3\right), 380 \mathrm{~nm}\left(\mathrm{C}^{3} \Pi_{\mathrm{u}} \rightarrow \mathrm{B}^{3} \Pi_{\mathrm{g}}, 0-2\right)$, the first negative system $\mathrm{N}_{2}{ }^{+}$in the bands $358 \mathrm{~nm}\left(\mathrm{~B}^{2} \Sigma_{\mathrm{u}}{ }^{+} \rightarrow\right.$ $\left.\mathrm{X}^{2} \Sigma_{\mathrm{g}}^{+}, 1-0\right), 391 \mathrm{~nm}\left(\mathrm{~B}^{2} \Sigma_{\mathrm{u}}^{+} \rightarrow \mathrm{X}^{2} \Sigma_{\mathrm{g}}^{+}, 0-0\right)$, the third set positive NOY in the band $258-259 \mathrm{~nm}\left(\mathrm{~A}^{2} \Sigma^{+} \rightarrow\right.$ $\left.\mathrm{X}^{2} \Pi, 0-3\right)$, O $777 \mathrm{~nm}\left(3 p^{5} P \rightarrow 3 s^{5} S^{\circ}\right)$ and He $396 \mathrm{~nm}\left(2 s^{1} S \rightarrow 4 p^{1} P^{\circ}\right), 400 \mathrm{~nm}\left(2 p^{1} P^{\mathrm{o}} \rightarrow 7 d^{1} D\right), 437 \mathrm{~nm}\left(2 p^{1} P^{\circ} \rightarrow\right.$ $\left.5 d^{1} D\right), 447 \mathrm{~nm}\left(2 p^{3} P^{\mathrm{o}} \rightarrow 4 d^{3} D\right), 587 \mathrm{~nm}\left(2 p^{3} P^{\mathrm{o}} \rightarrow 3 d^{3} D\right), 667 \mathrm{~nm}\left(2 p^{1} P^{\mathrm{o}} \rightarrow 3 d^{1} D\right), 706 \mathrm{~nm}\left(2 p^{3} P^{0} \rightarrow 3 s^{3} S\right), 729$ $\mathrm{nm}\left(2 p^{1} P^{0} \rightarrow 3 s^{1} S\right)$ and $781 \mathrm{~nm}\left(3 s^{3} S \rightarrow 7 p^{3} P^{0}\right)$. These bands and peaks have also been observed in previous 
works (Kieft et al., 2004; 2008; Martines et al., 2009).

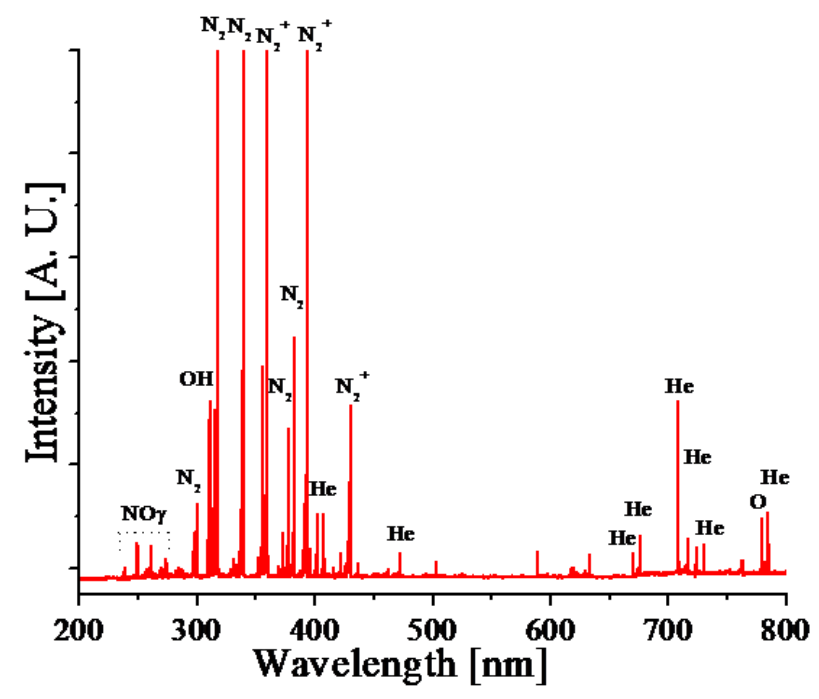

Figure 2. Helium plasma emission spectrum

While in former investigations using non-thermal plasma upon bacteria the idea was to probe its decontamination capacity, in the present work bacterial strains were used as an instrument to demonstrate that the toxic effect of this agent is due (at least partially) by the generation of RONS. Figure 3a shows the effect of the plasma needle upon E. coli strains; in both strains a significant cell removal is observed. For OG100 strain, survival decrease is one order of magnitude lower than PQ30 strain. This is because this strain is defective in genes involved in protection to oxidizing agents, so its absence makes it more sensitive to reactive oxygen species. The results suggest that ROS, produced by the helium plasma and identified in the spectrum, take part in the lethality of the strains. Recent studies has reported that reactive oxygen and nitrogen species (RONS) cause cell membrane damage (Moisan et al., 2002; Laroussi et al., 2004; Kong et al., 2009).

In 1985, Quillardet and Hofnung take advantage of the inducible character of the SOS system to create a test to detect genotoxic agents, known as the chromotest. The SOS induction factor indicates the ratio between non-treated control (basal SOS activity) and exposed bacteria (induced SOS activity), so its minimal value is 1 . Concerning chromotest results, no SOS induction was observed in any of the strain used. It can be seen in figure 3.b that there is no increment of the SOS activity along the exposure time, bringing up three possibilities: a) that plasma is not reaching the bacteria; b) that plasma treatments produce no DNA damage; c) that the toxicity of the plasma treatments is such that bacteria die before SOS genes translation occurs. The fact that there is an evident decrease in viability by plasma treatments discards the first hypothesis. Comet assay results (shown below) clearly indicate that, as reported before (Morales et al., 2013), plasma produces DNA fragmentation, most probably due to RONS. The latter proposal is supported by the fact that the activity of the alkaline phosphatase enzyme (which is included in the chromotest procedure to asses protein synthesis and indirectly to give an idea of toxicity) decreases as the dose increases (Figure 3c), being more evident in the case of the OG100 strain in accordance with survival. The results suggest that the RONS generated by the plasma causes membrane destruction, which leads to cell death (Laroussi et al., 2002; Stoffels et al., 2008, Kong et al., 2009). 

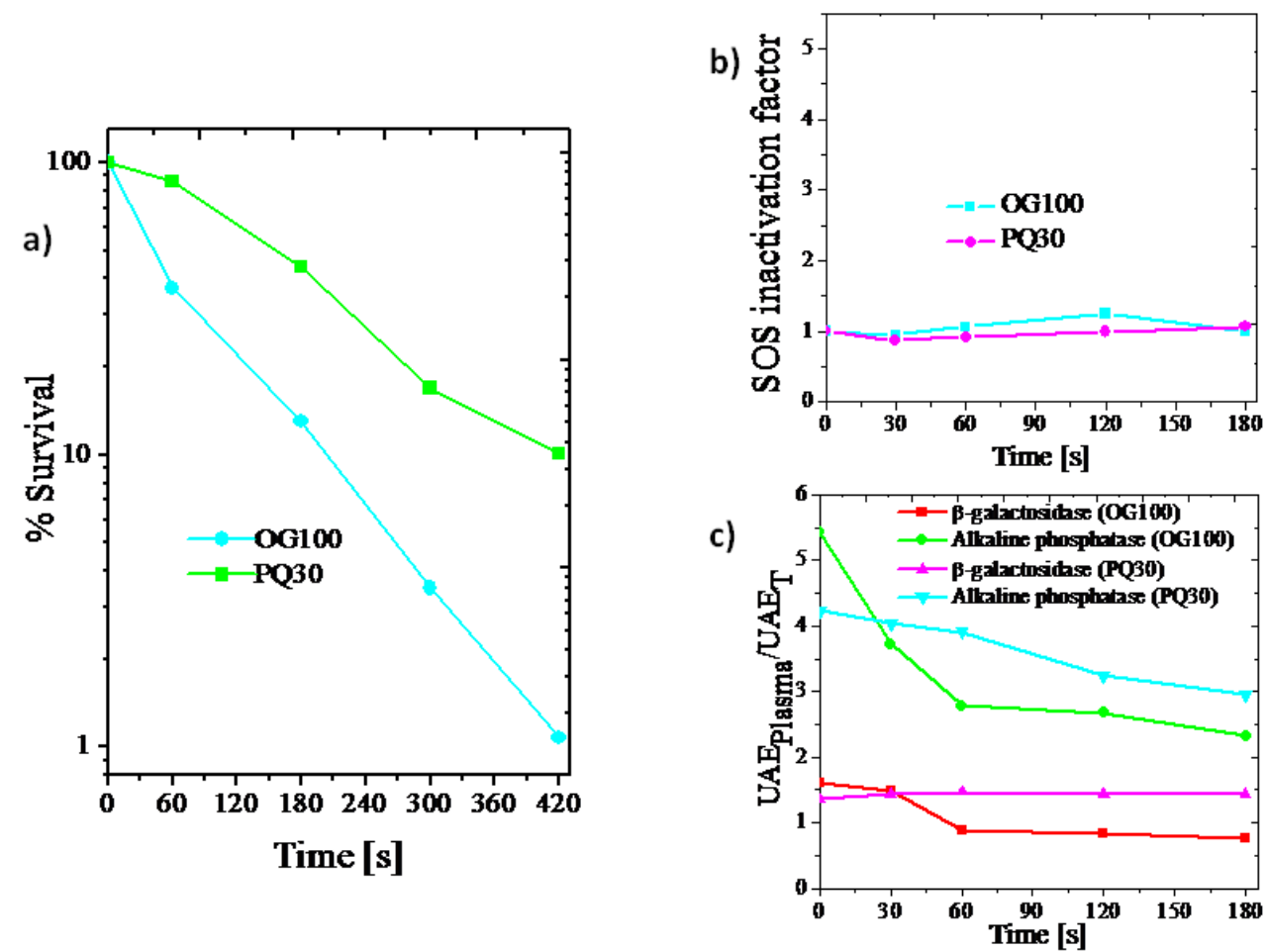

Figure 3. For PQ30 and OG100 E. coli strains a) survival, b) SOS response, c) SOS activity kinetics

Figure 4 shows the effect produced by the plasma needle on HeLa cells. As can be seen, the survival percentage decreases as the time of exposure increases, thus lowering from $39 \%$ within 15 seconds to $19 \%$ in 150 seconds. This phenomenon has been reported earlier by other authors (Kieft et al., 2005; Stoffels et al., 2006; Zimheld et al., 2010) and is considered to be caused by OH and NO radicals present in the plasma needle (Kieft et al., 2005; Stoffels et al., 2006), in accordance with bacteria survival results.

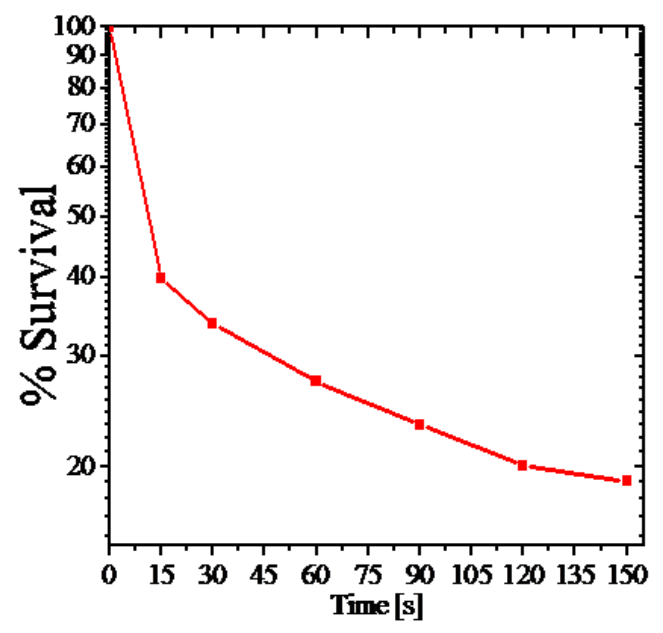

Figure 4. HeLa cell survival percent exposed to helium plasma needle

In the case of HeLa cells in a comet assay a control was included (Figure 5a) which allows distinguishing the DNA damages differences occurred with the needle plasma treatment. It was found a gradual DNA breakage as time elapses, from10 seconds up to total fragmentation in 30 seconds (see Figure $5 \mathrm{~b}$ to $5 \mathrm{e}$ ),. These results 
corroborate the toxicity as displayed in Figure 5.

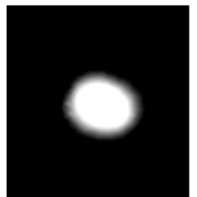

a)

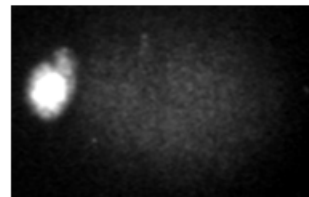

b)

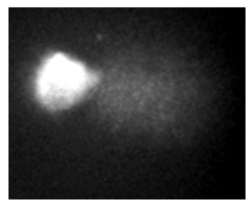

c)

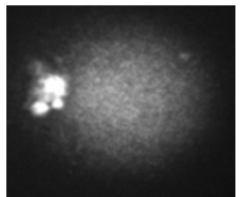

d)

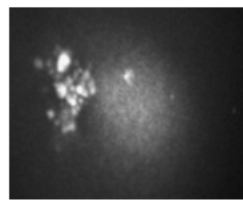

e)

Figure 5. Control and degradation of DNA as exposure function to plasma needle a) control, b) 10 seconds, c) 15 seconds, d) 20 seconds and e) 30 seconds

It must be pointed out the fact that the number of comets per field decreases as the exposure time increases, supporting the idea that cells disappeared prior its inclusion in the agarose matrix. In previous experiments Morales et al. (2013) included and lysed the cells before plasma treatment, thus naked DNA was exposed. In the present work, cells were treated and then slides were prepared, so the reduction in the number of comets per slide is due most probably to membrane disruption caused by RONS (Stoffels, 2006; Fridman, 2008).

\section{Conclusions}

The results obtained in HeLa and E.coli cells exposed to helium plasma needle clearly indicates that it produces an acute cytotoxicity in both eukaryotic and prokaryotic cells. In the case of the E. coli genotoxicity, was not observed, while the DNA damage upon HeLa cells showed to be proportional to the exposure time. The survival results with OG100 strain suggests that these effects were caused by the presence of RONS, generated by the interaction of the plasma needle with the environmental air. Furthermore, it is evident that the cell death either prokaryotes or eukaryotes is due to the disintegration of the cell, and not as a result of damage to the genetic material, reducing the possibility of generation of genetic mutations. This feature makes the plasma needle a good candidate in removal of microorganisms and as an alternative method especially in the oncology field.

\section{Conflict of Interests}

The authors declare that they have no competing financial or non-financial interests.

\section{Acknowledgements}

This work has received financial support from CONACYT, Mexico. The authors are grateful to the technical collaboration received from M. T. Torres Martínez, P. Angeles Espinoza and I. Contreras Villa.

\section{References}

Chen, F. F. (1984). Introduction, in: Introduction to plasma physics and controlled fusion (2nd ed.). New York, NY: Springer. http://dx.doi.org/10.1007/978-1-4757-5595-4

Cotelle, S., \& Férard, J. F. (1999). Comet assay in genetic ecotoxicology: a review. Environ. Mol. Mutagen., 34, 246-255. http://dx.doi.org/10.1002/(SICI)1098-2280(1999)34:4\%3C246::AID-EM4\%3E3.0.CO;2-V

Fridman, A. (2008). Plasma Biology and Plasma Medicine, in: Plasma Chemistry. New York, NY: Cambridge University Press. http://dx.doi.org/10.1017/CBO9780511546075

Fridman, G., Dobrynin, D., Mukhin, Y. V., Wynosky-Dolfi, M. A., Richard, F., Rieger R. J., ... \& Fridman, A. (2010). Cold plasma inactivation of Bacillus cereus and Bacillus anthracis (Anthrax) spores. IEEE T. Plasma Sci., 38, 1878-1884. http://dx.doi.org/10.1109/TPS.2010.2041938

Fridman, G., Shereshevsky, A., Jost, M. M., Brooks., Fridman, A., Gutsol A., ... Friedman G. (2007). Floating electrode dielectric barrier discharge plasma in air, promoting apoptotic behavior in melanoma skin cancer cell lines. Plasma Chem. Plasma P., 27, 163-176. http://dx.doi.org/10.1007/s11090-007-9048-4

Gallagher, M. J., Vaze, N., Gangoli, S., Vasilets, V. N., Gutsol, F. A., Milovanova, T. N., ... Fridman, A. (2007). Rapid inactivation of airborne bacteria using atmospheric pressure dielectric barrier grating discharge. IEEE T. Plasma Sci., 35, 1501-1510. http://dx.doi.org/10.1109/TPS.2007.905209

García-Alcantara, E., López-Callejas, R., Peña-Eguiluz, R., Lagunas-Bernabé, S., Valencia-Alvarado, R., Mercado-Cabrea, A., ... de la Piedad-Beneitez, A. (2012). Time effect and aliquot concentration in 
Streptococcus mutans elimination by plasma needle. J. Phys. Conf. Series., 370(012018).

Goerlich, O., Quillardet, P., \& Hofnung, M. (1989). Induction of the SOS response by hydrogen peroxide in various E. coli mutants with altered protection against oxidative DNA damage. J. Bacteriology., 171, 6141-6147.

Goore, J., Liu, B., \& Drake, D. (2006). Gas flow dependence for plasma-needle disinfection of S. mutans bacteria. J. Phys. D: Appl. Phys., 39, 3479-3486. http://dx.doi.org/10.1088/0022-3727/39/16/S05

Halliwell, B., \& Gutteridge, J. M. C. (1999). Antioxidant defences: endogenous and diet derived, in: Free radicals in biology and medicine. Free Radical Research, 31, 261-272. http://dx.doi.org/10.1080/10715769900300841

Kieft, E., Laan, E., \& Stoffels, E. (2004). Electrical and optical characterization of the plasma needle. New J. Phys., 6, 149. http://dx.doi.org/10.1088/1367-2630/6/1/149

Kieft, I. E., Darios, D., Rooks, A. J. M., \& Stoffels, E. (2005). Plasma treatment of mammalian vascular cells: a quantitative description. IEEE T. Plasma Sci., 33, 771-775. http://dx.doi.org/10.1109/TPS.2005.844528

Kogelschatz, U. (2003). Dielectric-barrier Discharges: Their history, discharge physics, and industrial applications. Plasma Chem. Plasma P., 23, 1-46. http://dx.doi.org/10.1023/A:1022470901385

Kong, G. M., Kroesen, G., Morfill, G., Nosenko, T., Shimizu, T., Van Dijk, J., \& Zimmermann, L. J. (2009). Plasma medicine: an introductory review. New J. Phys., 11, 115012. http://dx.doi.org/10.1088/1367-2630/11/11/115012

Laroussi, M. (1996). Sterilization of contaminated matter with an atmospheric pressure plasma. IEEE T. Plasma Sci., 24, 1188-1191. http://dx.doi.org/10.1109/27.533129

Laroussi, M. (2009). Low-temperature plasmas for medicine. IEEE T. Plasma Sci., 6, 714-724. http://dx.doi.org/10.1109/TPS.2009.2017267

Laroussi, M., \& Leipold, F. (2004). Evaluation of the roles of reactive species, heat, and UV radiation in the inactivation of bacterial cells by air plasmas at atmospheric pressure. Int. J. Mass Spectrom., 233, 81-86. http://dx.doi.org/10.1016/j.ijms.2003.11.016

Laroussi, M., Richardson, J. P., \& Dobbs, F. C. (2002). Effects of nonequilibrium atmospheric pressure plasmas on the heterotrophic pathways of bacteria and on their cell morphology. J. Appl. Phys., 81, 773-774.

Lerouge, S., Wertheimer, M. R., \& Yahia, H. (2001). Plasma sterilization: A review of parameters, mechanisms, and limitations. Plasmas Polym., 6, 175-188. http://dx.doi.org/10.1023/A:1013196629791

Léveillé, V., \& Coulombe, S. (2005). Design and preliminary characterization of a miniature pulsed RF APGD torch with downstream injection of the source of reactive species. J Plasma Sources Sci. T., 14, 467-476. http://dx.doi.org/10.1088/0963-0252/14/3/008

Martines, E., Zuin, M., Cavazzana, R., Gazza, E., Serianni, G., Spagnolo, S., ... Castagliuolo, I. (2009). A novel plasma source for sterilization of living tissues. New J. Phys., 11, 115014. http://dx.doi.org/10.1088/1367-2630/11/11/115014

Minuteman, model 305-SMP lambda-Minuteman Laboratories, Inc. (1979). 916 Main Street, Acton, Massachusetts. USA, MA 01720.

Moisan, J., Barbeau, S., Moreau, J., Pelletier, M., Tabrizia, M., \& Yahia, L. H. (2001). Low-temperature sterilization using gas plasmas: A review of the experiments and an analysis of the inactivation mechanisms. Int. J. Pharm., 226, 1-21. http://dx.doi.org/10.1016/S0378-5173(01)00752-9

Moisan, M., Boudam, M. K., Saoudi, B., Popovici, C., Gherardi, N., \& Massines, F. (2006). Bacterial spore inactivation by atmospheric-pressure plasmas in the presence or absence of UV photons as obtained with the same gas mixture. J. Phys. D: Appl. Phys., 39, 3494-3507. http://dx.doi.org/10.1088/0022-3727/39/16/S07

Morales-Ramírez, P. R., Cruz-Vallejo, V., Peña-Eguiluz, R., López-Callejas, R., Rodríguez-Méndez, B. G., Valencia-Alvarado, R., ... Muñoz-Castro, A. E. (2013). Assessing cellular DNA damage from a helium plasma needle. Radiat. Res. http://dx.doi.org/10.1667/RR3223.1

Nehra, V., Kumar, A., \& Dwivedi, H. K. (2008). Atmospheric non-thermal plasma sources. Int. J. Eng., 2, 53-68.

Peña-Eguiluz, R., Pérez-Martínez, J. A., Solís-Pacheco, J. R., Aguilar-Uscanga, B. R., López-Callejas, R., Mercado-Cabrera, A., ... de la Piedad-Beneitez, A. (2010). Instrumentation for a plasma needle applied to E. 
coli bacteria elimination. Eur. Phys. J. Appl. Phys., 49, 13109. http://dx.doi.org/10.1051/epjap/2009197

Pérez-Martinez, J. A., Peña-Eguiluz, R., López-Callejas, R., Mercado-Cabrera, A., Valencia-Alvarado, R., Barocio, S. R., \& de la Piedad-Beneitez, A. (2008). Power supply for plasma torches based on a class-E amplifier configuration. Plasma Process. Polym., 5, 593-598. http://dx.doi.org/10.1002/ppap.200800026

Quillardet, P., \& Hofnung, M. (1985). The SOS Chromotest, a colorimetric bacterial assay for genotoxins: procedures. Mutat. Res., 147, 65-78. http://dx.doi.org/10.1016/0165-1161(85)90020-2

Robert, E., Vandamme, M., Sobilo, J., Sarron, V., Ries, D., Dozias, S., ... Pouvesle, M. J. (2012). First achievements and opportunities for cancer treatment using non-thermal plasma. In: Machala, Z., Hensel, K., \& Akishev, Y. (Eds.), Plasma for Bio-Decontamination, Medicine and Food Security, Ed. Springer. Dordrecht, 381-392. http://dx.doi.org/10.1007/978-94-007-2852-3_29

Serment-Guerrero, J., Breña-Valle, M., \& Espinosa-Aguirre, J. J. (2008). In vivo role of Escherichia coli single-strand exonucleases in SOS induction by gamma radiation. Mutagenesis, 23, 317-323. http://dx.doi.org/10.1093/mutage/gen017

Sladek, R. E. J., Stoffels, E., Walraven, R., Tielbeek, P. J. A., \& Koolhoven, R. A. (2004). Plasma treatment of dental cavities: a feasibility study. IEEE T. Plasma Sci., 32, 1540-1543. http://dx.doi.org/10.1109/TPS.2004.832636

Stoffels, E. (2003). Plasma needle: Treatment of living cells and tissues. American Physical Society, 56 th Gaseous Electronics Conference, October 21-24, San Francisco, CA. http://dx.doi.org/10.1088/0963-0252/15/3/028

Stoffels, E., Gonzalvo, Y. A., Whitmore, T. D., Seymour, D. L., \& Ress, J. A. (2006). A plasma needle generates nitric oxide. Plasma Sources Sci. T., 15, 501-506. http://dx.doi.org/10.1088/0963-0252/15/3/028

Stoffels, E., Sakiyama, Y., \& Graves, B. D. (2008). Cold atmospheric plasma: charged species and their interactions with cells and tissues. IEEE T. Plasma Sci., 36, 1441-1457. http://dx.doi.org/10.1109/TPS.2008.2001084

Tice, R. R., Aqurell, E., Anderson, D., Burlinson, B., Hartmann, A., Kobayashi, H., ... Sasaki, Y. F. (2000). Single cell gel/comet assay: guidelines for in vivo genetic toxicology testing. Environ. Mol. Mutagen., 35, 206-221. http://dx.doi.org/10.1002/(SICI)1098-2280(2000)35:3\%3C206::AID-EM8\%3E3.0.CO;2-J

Vandamme, M., Robert, E., Lerondel, S., Sarron, V., Ries, D., Dozias, S., ... Pape, L. A. (2012). ROS implication in a new antitumor strategy based on non-thermal plasma. Int. J. Cancer., 130, 2185-2194. http://dx.doi.org/10.1002/ijc.26252

Walker, E. J., Gay, J. N., Saraste, M., \& Eberle, N. A. (1984). DNA sequence around the Escherichia coli unc operon. Completion of the sequence of a 17 kilobase segment containing asnA, oriC, unc, glmS and phoS. $J$. Biochem., 224, 799-815.

Witkin, E. M., \& Wermundsen, I. E. (1979). Targeted and untargeted mutagenesis by various inducers of SOS functions in Escherichia coli. C.S.H. Symposia, 43, 881-886. http://dx.doi.org/10.1101/SQB.1979.043.01.095

Yonson, S., Coulombe, S., Léveillé, V., \& Leask, L. R. (2006). Cell treatment and surface functionalization using a miniature atmospheric pressure glow discharge plasma torch. J. Phys. D: Appl. Phys., 39, 3508-3513. http://dx.doi.org/10.1088/0022-3727/39/16/S08

Zimheld, L. J., Zucker, N. S., Disanto, M. T., Berezney, R., \& Etemadi, K. (2010). Nonthermal plasma needle: development and targeting of melanoma cells. IEEE T. Plasma Sc., 38, 948-952. http://dx.doi.org/10.1109/TPS.2010.2041470

\section{Copyrights}

Copyright for this article is retained by the author(s), with first publication rights granted to the journal.

This is an open-access article distributed under the terms and conditions of the Creative Commons Attribution license (http://creativecommons.org/licenses/by/3.0/). 